Review

\title{
Bond strength characterization of commercially available grouts for masonry
}

\author{
Eduarda Luso ${ }^{\mathrm{a}, *}$, Paulo B. Lourenço ${ }^{\mathrm{b}}$ \\ a ISISE, Polytechnic Institute of Bragança, Department of Civil Constructions, Campus Sta Apolónia, 5300-253 Bragança, Portugal \\ ${ }^{\mathrm{b}}$ ISISE, University of Minho, Department of Civil Engineering, Azurém, 4800-058 Guimarães, Portugal
}

\section{H I G H L I G H T S}

- Bond strength is one of the most important properties of grout injection technique.

- Strength depends significantly on the substrate and its condition.

- Different results were obtained for the same grout varying the support and the moisture content of the substrate.

- An average tensile bond strength of $0.8 \mathrm{MPa}$ at 28 days was obtain for three types of stone for one of the studied grouts.

- A higher compression strength does not necessarily mean higher values of bond strength capacity.

\section{A R T I C L E I N F O}

\section{Article history:}

Received 15 September 2016

Received in revised form 17 March 2017

Accepted 21 March 2017

Available online 2 April 2017

\section{Keywords:}

Bond strength

Grouts, masonry

Injection

\begin{abstract}
A B S T R A C T
Heritage masonry structures often show signs of deterioration due to ageing, soil settlements, extreme events or other actions. Repairing these structures using grout injection is an interesting technique since it preserves the historical character of the existing materials, even if filling voids and bringing a bonding addition. A high-performance grout for use in these structural repairs should meet several performance criteria, including fluidity, strength, compatibility and durability. The main objective of this study is to assess the bond characteristics of four commercially available (CA) grouts available in Europe, as this is possibly the most needed mechanical performance of grouts. The bond mechanism was studied in composite grout/stone specimens, as the shear bond strength of the grout-stone interface is the main property affecting the behaviour of grouted walls. In-depth characterization of the tensile strength of the interface between grout and stone required the preparation of specimens with the selected CA grouts and three usual stones in historical buildings: limestone, schist and yellow granite. The moisture content of the stones was also varied, as this is difficult to control in real case studies. Therefore, the tests were performed with dry, moist and saturated stones. Significant differences were found between the different grouts, stressing the need for adequate material selection.
\end{abstract}

(c) 2017 Elsevier Ltd. All rights reserved.

\section{Contents}

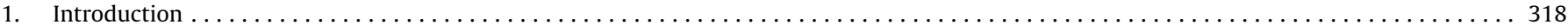

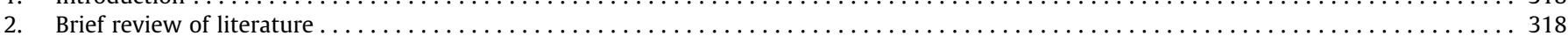

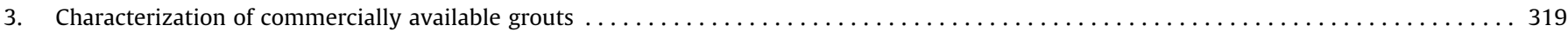

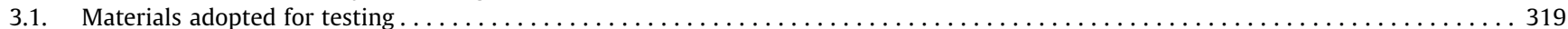

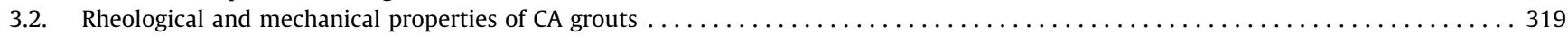

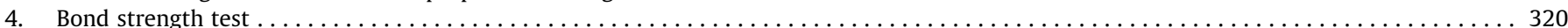

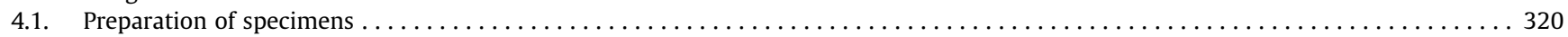

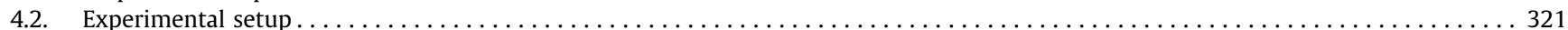

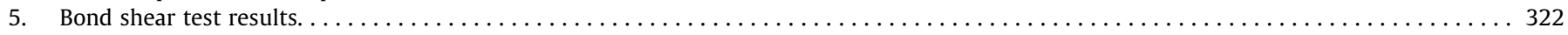

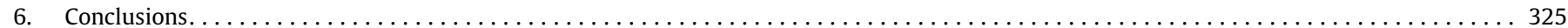

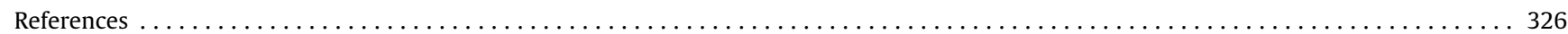

\footnotetext{
* Corresponding author.

E-mail addresses: eduarda@ipb.pt (E. Luso),pbl@civil.uminho.pt (P.B. Lourenço).
} 


\section{Introduction}

Cement and lime-based grouting is a well-known repair and strengthening method. This intervention technique can be durable and mechanically efficient whilst preserving the historical value of the structure, mainly in the case of the quite frequent type of three-leaf masonry, since the materials added to the masonry may be of the same nature as the "in-situ" ones [1]. Good results in the application of this technique can be obtained only if the injection materials are compatible with heterogeneous elements such as masonry stone walls. The use of a grout that is incompatible with the environment where it will be applied may cause the appearance of further deterioration related to the mechanical behaviour or chemical reactions with existing materials [2]. This can jeopardize not only the desired consolidating effect but also the stability conditions that existed before the injection [3]. The definition of the composition of a grout that is compatible with the characteristics of the support is an obstacle to the use of this technique due to the influence of numerous parameters, such as the shape and dimensions of the stones, chemical composition, porosity, absorption capacity, percentage of voids, or dimension of voids and their communication.

Grouts should comply with a number of requirements for their application in old buildings, namely to: (i) ensure a good bond to existing masonry materials, including stone or brick; (ii) have low or no shrinkage, to maintain the volume without developing large tensile stresses, in order to avoid the loss of bonding and to reduce moisture penetration through cracks caused by shrinkage; (iii) have low segregation and exudation to maintain the volume and consistency; (iv) possess high fluidity to provide adequate drainage and fill small openings and interconnected voids, even using low pressures; ( $v$ ) have soluble salt resistance. Other properties may be required, such as the need for developing resistance in the early days, the need for deciding whether or not (larger) aggregate is present in the composition of the grout, the need to have compatible mechanical strength and elastic modulus to the substrate, or the need to have similar thermal properties [2,4-7].

Despite these requirements, one of the most important aspects in grout injection is the strength of the bond to the substrate. This is an essential requirement, because the interface between the new binding material and the support is usually the weakest link from the mechanical point of view, affecting significantly the resistance of the masonry and its durability. In masonry, the role of bonding materials (injecting grout or existing mortar) is to provide continuity throughout the various components of the masonry. Binda et al. [8] provide one of the first descriptions of the function of the grout within three-leaf walls and show, although not clearly, that the adhesion of the grout is more important than other mechanical properties in grout formulation. Similar subsequent studies carried out by Binda et al. [9] and Vintzileou [1] show that, in the case of weak masonry joints without through stones between multiple leaves, it is the bond strength between the units and the vertical joint mortar and not the compressive strength of each element that controls the compressive strength of the walls. According to Toumbakari et al. [10], the separation between the outer and inner leaves in masonry walls is directly linked to the bond strength. In addition, in-plane shear strength and out-of-plane failure (either due to disintegration of the wall or in the form of rocking macroblocks), which is the most relevant failure mode in the case of seismic action in historic masonry buildings, are directly linked to the bond strength. For these reasons, the current study addresses the bond strength of four commercial grouts available in Europe, measuring how they perform when applied in three different stone types (granite, limestone and schist), with different moisture conditions (dry, moist and saturated).

\section{Brief review of literature}

It is known that the compressive strength of the grout can serve as a very rough estimation for the evaluation of the compressive strength and Young's modulus of the injected walls [11-13]. But the intrinsic mechanical properties of grouts are not the key properties, and it is rather the bond shear strength to the substrate [14] that controls the injection efficiency [15]. The bond mechanism incorporates two mechanisms: chemical and mechanical bond connection. The chemical bond is related to the chemical reactions between the linked materials (grout, mortar) and the substrate, where covalent and van der Waals forces contribute to the bond between the masonry units and the hydrates binder [4-6]. The mechanical connection is formed by a mechanical interconnection of the hydration products transferred to the pores of the support surface [16].

In the case of grout injection, the adhesion depends on many interrelated factors that can directly or indirectly affect its development, namely: porosity [17], absorption, moisture content and texture of the substrate surface $[18,19]$, type of binder, the presence of pozzolans, water retention capacity of the solution, curing conditions [16] and the amount of water used in the mixture [20].

In fact, the characteristics of the surface absorption and the amount of water available in grout control, to a great extent, the volume of water that moves from the grout to the support [16], which provides a greater or lesser consolidation of hydration products in the grout-unit interface. The amount of mixing water and the retention capacity of the grout can set the amount of water available at the interface and thus the development of the hydration products in the pores of the support surface [16]. Therefore, the optimization between the required and provided water in the grout-support interface may be the key to the successful development of the adhesion of grout to the support [21,22].

The bond strength is also dependent on the presence of powders and fine loose material in the support, in particular clay, which may occupy large portions of volume, particularly in three-leaf walls, and which is hardly permeable to the grout [23], preventing adequate grouting [24].

As the main function of grout injection is to connect the various elements of the masonry to each other, there is a need to focus on maximizing the adhesion and tensile strength of the solution, rather than other mechanical properties. The performance of the bond is not proportional to the resistance to compression and tension of the grout itself. Grouts produced with materials similar to those in the existing structure may be effective, despite their low mechanical properties, and, when compared with cement-only grouts, can simultaneously ensure a better structure durability $[1,12]$. The first tests regarding the characterization of the bond strength of grout on limestone substrates were performed by Miltiadou ([25] (see Table 1). But other studies concerning the adhesion ability of grout injection on stony materials of different nature have been done by Adami et al. [15] and Adami and Vintzileou [7] (see Table 2 and Table 3), and in brick substrate $[16,26]$. The optimization of the properties of the grout, in addition to the local environment, depends on the right choice of raw materials, as well as their proportions and performance technique.

Given the importance of the bond in the efficacy of grout injection for consolidation and strengthening, and knowing that only a few studies deal with this issue in stone masonry [15], the need for a systematic study concerning this theme is clear. The results just presented indicate a clear influence of the grout composition, the moisture level of the substrate and the type of substrate. They also show that no direct correlation seems to exist between the grout's compressive strength and the bond strength. As commercial grouts are often used in practice, given their availability, ease of use and 
Table 1

Tensile bond strength results in grout/stone specimens (MPa) by Miltiadou (1991) [25].

\begin{tabular}{|c|c|c|c|c|c|c|c|c|c|}
\hline \multirow[t]{2}{*}{ Grout composition } & \multicolumn{3}{|c|}{$\mathrm{d}=1 \mathrm{~mm}^{*} /$ dry stone } & \multicolumn{3}{|c|}{$\mathrm{d}=3 \mathrm{~mm} /$ dry stone } & \multicolumn{3}{|c|}{$\mathrm{d}=1 \mathrm{~mm} /$ wet stone } \\
\hline & SM & $\mathrm{L}$ & $\mathrm{E}$ & SM & $\mathrm{L}$ & $\mathrm{E}$ & SM & $\mathrm{L}$ & $\mathrm{E}$ \\
\hline $100 \%$ CEM & 0.6 & 2.2 & - & - & - & - & - & - & - \\
\hline $75 \% \mathrm{CEM}+25 \% \mathrm{SF}$ & 2.1 & 4.0 & 1.8 & 2.3 & 3.0 & 1.3 & 1.3 & 2.4 & 1.0 \\
\hline $75 \% \mathrm{CEM}+25 \% \mathrm{CL}$ & 1.8 & 2.9 & 1.3 & 1.5 & 3.0 & 1.1 & 1.2 & 1.7 & 0.5 \\
\hline $50 \% \mathrm{CEM}+22.5 \% \mathrm{SF}+27.5 \% \mathrm{CL}$ & 2.0 & 3.0 & 0.9 & 1.2 & 1.6 & 0.8 & 0.7 & 2.0 & 0.6 \\
\hline
\end{tabular}

CEM - cement; CL - hydrated lime; SF - silica fume; SM, L and E - different limestone.

Joint thickness.

Table 2

Bond strength results in grout/stone specimens by Toumbakari et al. [4,5].

\begin{tabular}{|c|c|c|c|}
\hline Grout composition & Compressive strength at 28 days (MPa) & Bond strength in limestone (MPa) & $40 \mathrm{~mm}$ \\
\hline $17.5 \% \mathrm{CL}+52.5 \% \mathrm{PZ}+30 \% \mathrm{CEM}$ & 3.2 & 1.63 & \\
\hline $11.7 \% \mathrm{CL}+58.3 \% \mathrm{PZ}+30 \% \mathrm{CEM}$ & 3.5 & 1.35 & \\
\hline $17.5 \% \mathrm{CL}+42.5 \% \mathrm{PZ}+30 \% \mathrm{CEM}+10 \% \mathrm{SF}$ & 6.5 & 1.47 & \\
\hline
\end{tabular}

CEM - cement; CL - hydrated lime; SF - silica fume; PZ - pozzolan.

Table 3

Summary of bond strength test results in grout/stone specimens by Adami et al. [15]

\begin{tabular}{|c|c|c|c|c|}
\hline \multirow[t]{2}{*}{ Grout composition } & \multirow[t]{2}{*}{ Compressive strength at 28 days ( $\mathrm{MPa}$ ) } & \multicolumn{3}{|c|}{$\begin{array}{l}\text { Bond strength marble } / \text { travertine } \\
(\mathrm{MPa})\end{array}$} \\
\hline & & 28 days & 90 days & 180 days \\
\hline $80 \% \mathrm{CEM}+20 \% \mathrm{CL}+\mathrm{SP} ; \mathrm{w} / \mathrm{s}=0.8-0.9$ & 14.6 & $0.93 / 1.57$ & - & - \\
\hline $30 \% \mathrm{CEM}+35 \% \mathrm{CL}+35 \% \mathrm{MK}+\mathrm{SP} ; \mathrm{w} / \mathrm{s}=1.1$ & 9.9 & $-/ 1.35$ & $0.85 / 1.41$ & $-/ 1.85$ \\
\hline $30 \% \mathrm{CEM}+47 \% \mathrm{CL}+23 \% \mathrm{PZ}+\mathrm{SP} ; \mathrm{w} / \mathrm{s}=0.8-0.9$ & 7.3 & $0.33 / 1.48$ & $-/ 1.72$ & $0.59 / 1.65$ \\
\hline
\end{tabular}

CEM - cement; CL - hydrated lime; SP - superplasticizer; PZ - pozzolan; MK - metakaolin; w/s - water/solid materials.

Porosity $0,2 \%$

${ }^{* *}$ Porosity $2,9 \%-16,8 \%$

quality control, it is relevant to carry out an extensive study on their bond strength performance.

\section{Characterization of commercially available grouts}

\subsection{Materials adopted for testing}

The use of lime-pozzolan-cement grouts for the consolidation of ancient stone masonry walls seems to be one of the most attractive options [4-6], with potentially very good properties. The effectiveness of these compositions has been proven by experimental studies carried out in one- and three-leaf walls $[4,10,12,13,27,28]$. The formulation of these grouts remains, to a large extent, an empirical action [29,30]. Then, selection should be based on laboratory tests, aiming at choosing the best material suited for each case [1]. However, pre-mixed grouts available in the market from specialized companies are often used in practice, mainly because of their easy preparation and availability. Still, scarce information is available about these materials, besides what is provided in the respective technical data sheets by the manufacturers.
The experimental program presented in this paper focuses mainly on the study of the bond strength of injection grouts available in Europe with three different types of stone, namely yellow granite (YG), limestone (LM) and schist (SC), commonly used in ancient masonry walls existing in Portugal (see Fig. 1). The grouting materials chosen for this study were: Mape-antique I, from Mapei, Albaria Iniezione from BASF, Calce per Consolidamento from Cepro and Lime-Injection from Tecnochem. These products are denoted hereafter by $A, B, C$ and $D$ respectively, for conciseness. The description and the properties of each grout according to the respective producer are presented in Luso and Lourenço [31].

\subsection{Rheological and mechanical properties of CA grouts}

In order to characterize their physical, rheological and mechanical behaviour, several preliminary laboratory tests were conducted to determine the fresh and hardened properties of the four commercially available (CA) grouts used to repair masonry: flow time; bleeding; segregation and compressive strength.

To determine the fluidity of the CA injection grouts, tests with a conical funnel with normalized and calibrated dimensions (com- 

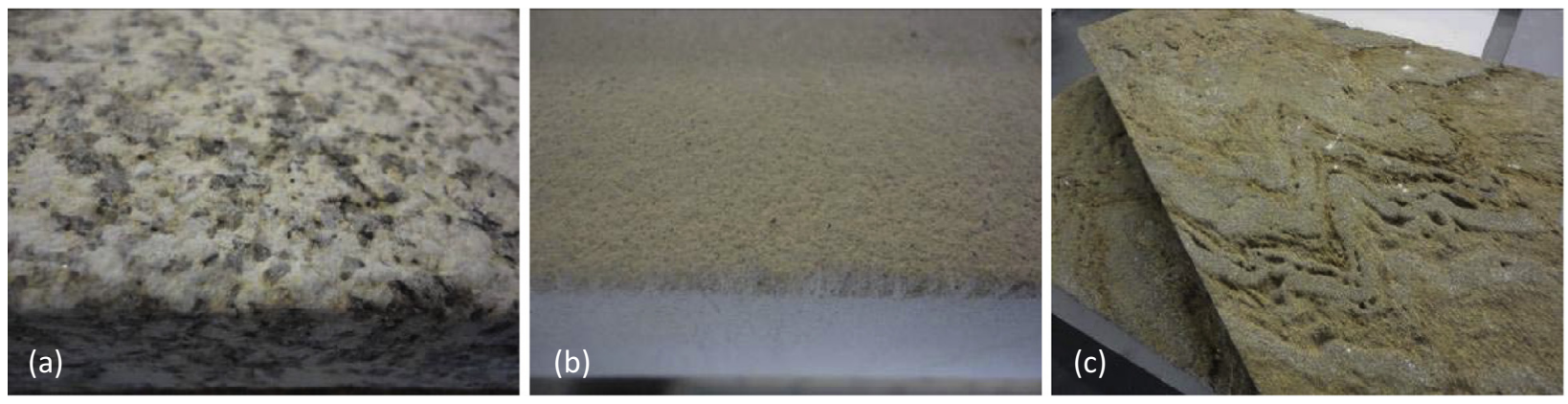

Fig. 1. Aspect of the stones used in the tests: (a) yellow granite (YG); (b) limestone (LS); (c) schist (SC).

monly known as a Marsh cone) were carried out and the flow time of a given volume of solution was recorded. Six series of tests were performed with each of the products, varying the mixing water temperature and the environment between $10^{\circ} \mathrm{C}, 20^{\circ} \mathrm{C}$ and $30^{\circ} \mathrm{C}$. The tests for bleeding and segregation were performed according to standard EN 445 [32] and established in ASTM 940 [33]. The compressive strength was measured for each grout in six half-prisms obtained by flexural rupture of three prisms. The test procedure followed standard EN 445 [32] and it was slightly adapted from EN 196-1 [34], used for cement mortars, as done in similar investigations [4-6,23]. The injection grouts were also evaluated in terms of injectability and penetration. With this purpose, the CA grouts were injected into transparent cylindrical moulds. The moulds were filled with different stone types and sizes, in order to reproduce typical masonry materials. The specimens were cured after demoulding at a temperature $\mathrm{T}=20^{\circ} \mathrm{C}$ and $90 \%$ of relative humidity RH. At 28 and 90 days of curing, uniaxial compression tests were performed with displacement control, together with indirect tensile tests or diagonal compression tests. The tested cylinders were subjected to visual inspection after failure in order to study the penetration of the grout, as done in other studies [11$13,23,24,35]$.

The investigation of the four CA grout properties revealed significant variations in the measurements of their properties. All the test procedures and final results are described in Luso and Lourenço [31]. The main results obtained from that investigation are summarized in Table 4 . The tests demonstrated a good stability with low bleeding and segregation for all grouts, although product $D$ needs careful handling because it tends to stratify. In terms of fluidity, the test results obtained indicate significant changes to this property with temperature. Grouts $A, B$ and $D$ behave better in terms of fluidity at $30^{\circ} \mathrm{C}$. Lower temperatures $\left(10^{\circ} \mathrm{C}\right)$ seem to negatively influence the fluidity of these materials. Although the flow times obtained were, in some cases, higher than the values prescribed in the standards, the fluidity observed during cylinder injection was satisfactory. The same happened with product $C$, which did not flow in the Marsh cone test, but showed overall a good workability and an adequate behaviour in the injection of the cylinder mould.

Regarding the mechanical properties of the four CA grouts, testing revealed some similarity in grouts $A$ and $B$ (not considering the bond strength capacity), with similar values, both of the axial compression strength of the grout and grout/stone, as well as in diagonal compression tests. The tensile strength of diametral compression is, in this case, about $1 / 10$ of the axial compression. For products $A$ and $C$ this value is about $1 / 7$. Sorting the grouts by the values obtained in mechanical tests, from highest to lowest, we have $B, A, D$ and $C$. From the analysis of the interior of the specimens after diametral tests, all grouts satisfy the injectability requirements in the cylinders, achieving a good filling and sufficient bond between the grout and stones, for this action.

\section{Bond strength test}

\subsection{Preparation of specimens}

As indicated above, research on bond mechanisms in stone-togrout interfaces has been carried out by Adami et al. [15], Perret et al. [39], Toumbakari et al., [4,5], Miltiadou [25] and Figueiredo [26] using prismatic and cylindrical test pieces. In the absence of

Table 4

Resumé of the main properties of the CA grouts.

\begin{tabular}{|c|c|c|c|c|}
\hline & $A$ & $B$ & C & $D$ \\
\hline Flow time $\left(10^{\circ} \mathrm{C}\right)^{*}$ & $100 \mathrm{~s}$ & $40 \mathrm{~s}$ & - & $81 \mathrm{~s}$ \\
\hline Flow time $\left(20^{\circ} \mathrm{C}\right)^{*}$ & $79 \mathrm{~s}$ & $79 \mathrm{~s}$ & - & $39 \mathrm{~s}$ \\
\hline Flow time $\left(30^{\circ} \mathrm{C}\right)^{*}$ & $54 \mathrm{~s}$ & $55 \mathrm{~s}$ & - & $50 \mathrm{~s}$ \\
\hline Bleeding (ASTM 940) & $3.1 \%$ & $0.2 \%$ & $1.3 \%$ & $1.5 \%$ \\
\hline Bleeding (EN 445) & $2.0 \%$ & $0.1 \%$ & $1.1 \%$ & $1.4 \%$ \\
\hline Compressive strength at 28 days & 19.6 MPa & $22.0 \mathrm{MPa}$ & $1.5 \mathrm{MPa}$ & $12.0 \mathrm{MPa}$ \\
\hline Compressive strength at 360 days & $31.0 \mathrm{MPa}$ & $32.0 \mathrm{MPa}$ & $4.2 \mathrm{MPa}$ & $16.8 \mathrm{MPa}$ \\
\hline Injectability in schist ${ }^{*}$ & $100 \mathrm{~s}$ & $106 \mathrm{~s}$ & $84 \mathrm{~s}$ & $80 s$ \\
\hline Injectability in granite & $422 \mathrm{~s}$ & $234 \mathrm{~s}$ & $527 s$ & $164 \mathrm{~s}$ \\
\hline Injectability in limestone & $272 \mathrm{~s}$ & $155 \mathrm{~s}$ & $138 \mathrm{~s}$ & $171 \mathrm{~s}$ \\
\hline Compressive strength at 28 days & $23.2 \mathrm{MPa}$ & $21.1 \mathrm{MPa}$ & 1.0 MPa & $7.3 \mathrm{MPa}$ \\
\hline Elastic modulus at 28 days & $21.3 \mathrm{GPa}$ & $20.6 \mathrm{GPa}$ & - & $5.95 \mathrm{GPa}$ \\
\hline Diametral strength at 28 days $\sharp$ & $2.0 \mathrm{MPa}$ & $2.2 \mathrm{MPa}$ & $0.1 \mathrm{MPa}$ & $0.9 \mathrm{MPa}$ \\
\hline
\end{tabular}

Flow time of 1 litre grout after mix.

** In $500 \mathrm{ml}$ glass beaker.

*** In $100 \mathrm{ml}$ glass graduated cylinder.

* Total filling time of acrylic cylinders ( $\varnothing=150 \mathrm{~mm}$ e $\mathrm{h}=300 \mathrm{~mm}$ ) with $\sim 50 \%$ volume of voids

- Results of compressive tests in the cylinders with yellow granite.

- Test according to specification LNEC E397 [36] and ASTM C469 [37].

$\sharp$ Test according the standard EN 12390-6 [38]. 


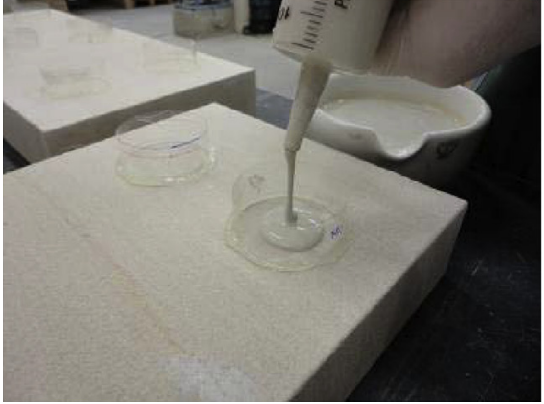

(a)

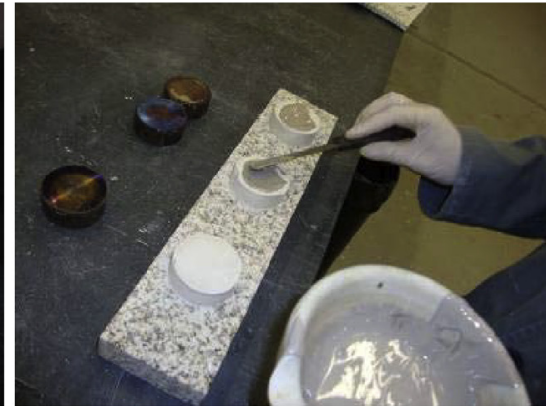

(b)

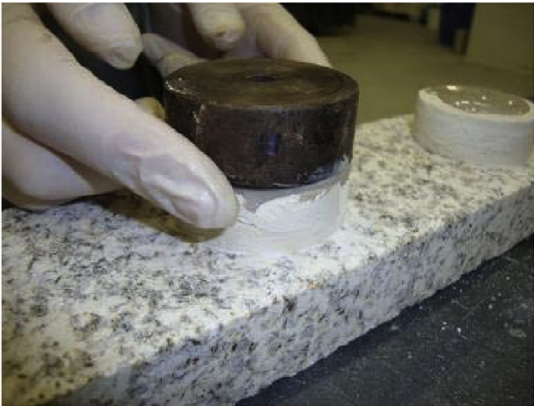

(c)

Fig. 2. Sequence for specimens preparation: (a) grout filling of disk with syringe; (b) application of epoxy after disk curing; (c) gluing of pulloff disk.

standards that stipulate the test setup and the preparation of the samples, preliminary tests were performed in this study. The main goal was to define a suitable method of specimen preparation (assembly, shape and geometry of the specimen) and the grout injection process. After the preliminary tests, it was decided to characterize the bond mechanism in stone-to-grout interfaces using pulloff tests. The pulloff tests determined the maximum traction force applied in a circular area of grout applied to the substrate.

The preparation of the specimens began by cutting the pieces of granite, limestone and schist with dimensions that allow three to six tests to be performed per piece. Each stone was then sandblasted to provide surface roughness. After washing and drying the pieces, a transparent plastic film about $48 \mathrm{~mm}$ in diameter and with a height of $25 \mathrm{~mm}$ was glued on the stones (see Fig. 2 (a)). Three different states of moisture content were considered for the stones: (i) "wet" when the stones were placed in a humid chamber for at least two weeks, with $\mathrm{T}=20^{\circ} \mathrm{C} \pm 2{ }^{\circ} \mathrm{C}$ and $\mathrm{RH} \approx 95 \%$; (ii) "dry" when the stones were placed in the laboratory in the open air; (iii) "saturated" when pieces were submerged in water $\left(\mathrm{T}=20^{\circ} \mathrm{C}\right)$ for $24 \mathrm{~h}$ before testing. For granite and limestone, these three scenarios were considered. In the case of schist, it was not possible to carry out tests with saturated stone, because the plastic moulds detached easily.

After the stones were prepared, the four commercial products were prepared according to the manufacturers' recommendations and mixed for $10 \mathrm{~min}$ to obtain a homogeneous material. Before placing in the transparent mould, the grout was sieved to eliminate any clog that had formed. Each CA grout was applied on the stone pieces, in three circular moulds injected with a syringe, to obtain a $20 \mathrm{~mm}$ height solution (see Fig. 2(a)). This manual injection process was easier for products $C$ and $D$ than for products $A$ and $B$.
The specimens thus formed (stone + grout) were subjected to curing in a humid chamber with $\mathrm{T}=20^{\circ} \mathrm{C} \pm 2{ }^{\circ} \mathrm{C}$ and $\mathrm{RH} \approx 95 \%$. The mould release (removal of transparent tape) occurred about two weeks after the preparation of the test specimens. In order to level the surface of the grout specimens and remove the bright skin that forms in some of the grouts, the surface was ground with fine sandpaper. Approximately $48 \mathrm{~h}$ before the tensile test, circular metal discs with a diameter of $48 \mathrm{~mm}$ were fitted on one side of a centred thread and they were glued with high strength epoxy resin (see Fig. 2(b and c)).

Product $C$ presented, for most specimens, transverse cracking at the upper edges, most likely due to shrinkage, sometimes separating the grout specimen into two parts and therefore conditioning the results (see Fig. 3). Product $D$ showed a variation of colour and texture over the height of the disk, with stratification. This phenomenon is not surprising, given the exudation/segregation tests. Products $A$ and $B$ present, in general, a smooth texture and a uniform colour with no cracking.

\subsection{Experimental setup}

Subsequently, the samples were tested at 28 and 90 days of age. The pulloff tests were performed in the Structures Laboratory of the University of Minho, in Guimarães. The bond stress $\left(f_{d}\right)$ is the ratio of the force obtained $\left(F_{t}\right)$ and the initial section area of specimen grout $(A)$.

$f_{d}=\frac{F_{t}}{A}$

Three LVDT's of $\pm 2.5 \mathrm{~mm}$ were placed at a $120^{\circ}$ angle in the sample (see Fig. 4), allowing one to obtain stress-displacement diagrams only up to the maximum value of the stress (see Fig. 5).
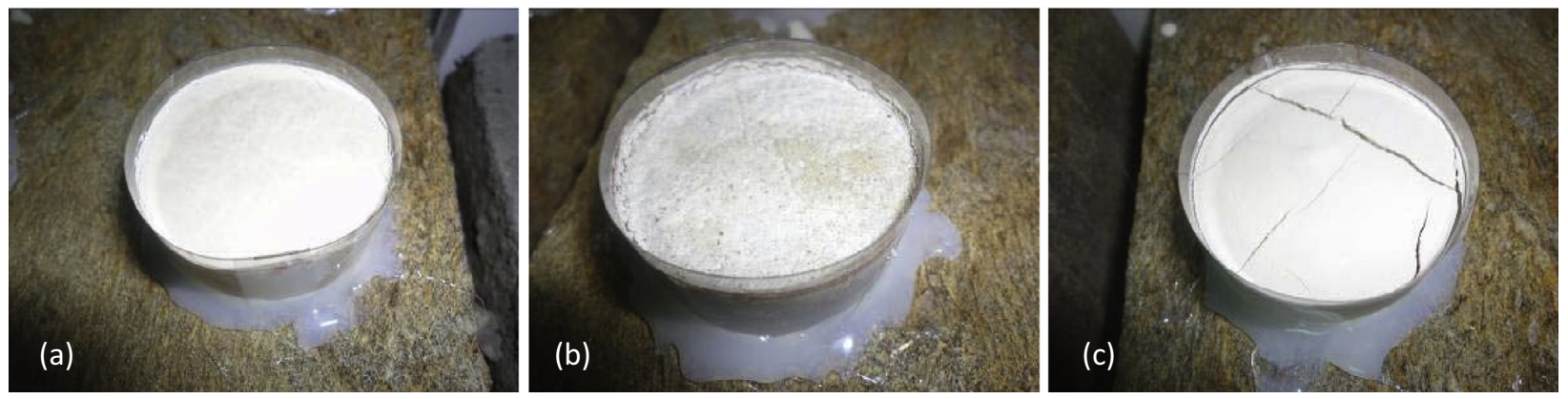

Fig. 3. Aspect of the test pieces after a few days of curing and before demoulding: (a) $A$; (b) $D$ and (c) $C$ 


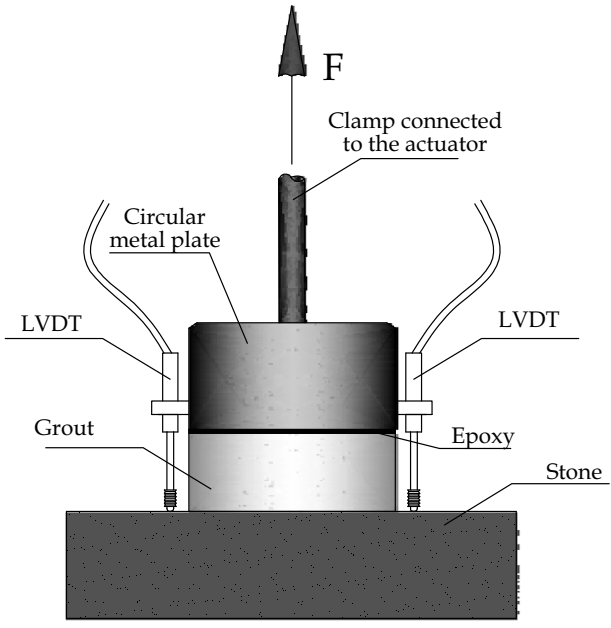

(a)

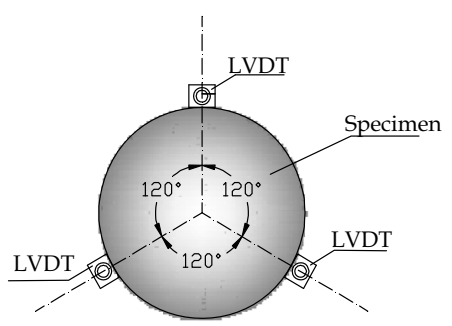

(b)

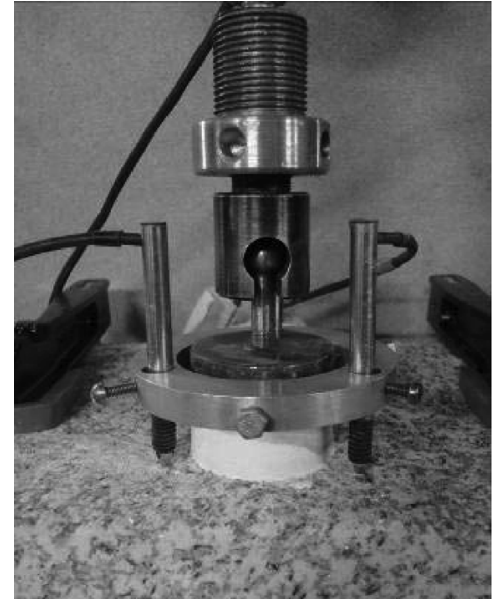

(c)

Fig. 4. (a) Test setup; (b) Detail of LVDT placement; (c) Tests in granite stone.

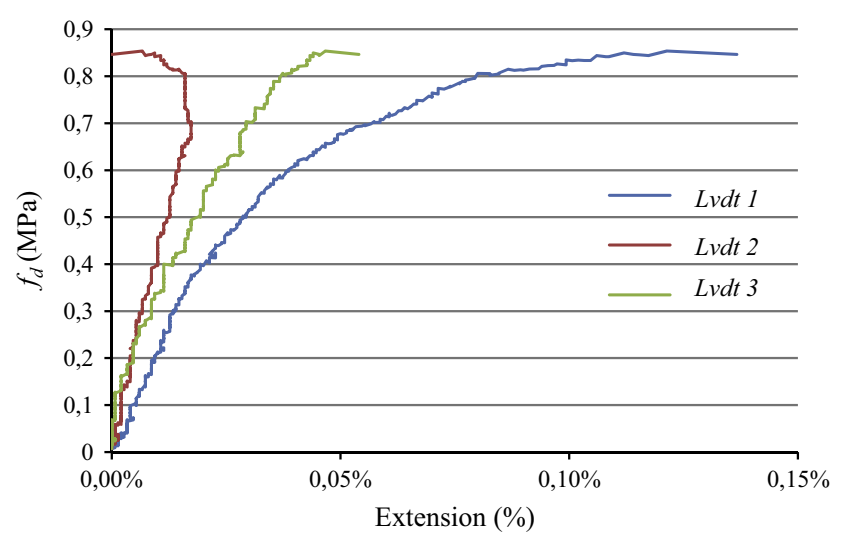

Fig. 5. Experimental result on the tensile bond strength of the interface between the $A$ grout and yellow granite.

Rotation and uneven failure of the specimen is obtained, which is common for localized failure in quasi-brittle materials. The tests were performed under displacement control at a rate of $2 \mu \mathrm{m} / \mathrm{s}$.

\section{Bond shear test results}

For each pulloff test, the failure mode obtained was identified. The knowledge of the type of failure is essential because the ultimate strength obtained in the test can be the bond strength of the interface or a lower limit, depending on whether the fracture is adhesive or cohesive [40]. The bond failure can occur between the grout and stone (denoted in what follows next as "interface") or between the grout and the circular metal plate (denoted as "glue") (see Fig. 6(a and b)). In the case when the fracture occurs in the glue, the test is considered unsuccessful, and the value obtained is a minimum pulloff strength for this specimen type. When fracture occurs within the grout or at the support, it is called a cohesive fracture (Fig. $6 \mathrm{c}$ and d). Next, this fracture is denoted as "grout" and "stone", respectively. It is noted that several failures involve mixed modes.

Tables 5-7 present the average values of the tensile bond strength obtained in each three of the 168 samples tested. In some cases tests were repeated because the results were suspicious or the test pieces came off naturally from the stone during demoulding. In the tables, additional notes appear for each test, including the number of specimens tested and the type of fracture observed.

Figs. 7-11 present graphically all the tensile bond strength results for easier comparison. The overall analysis indicates that

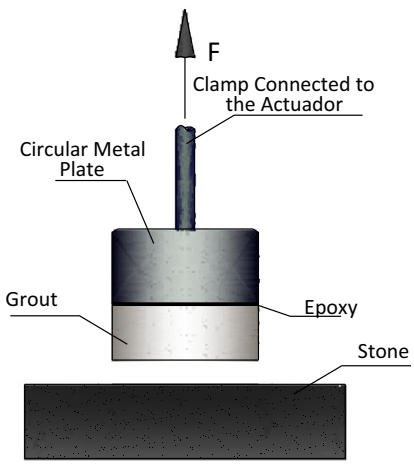

(a)

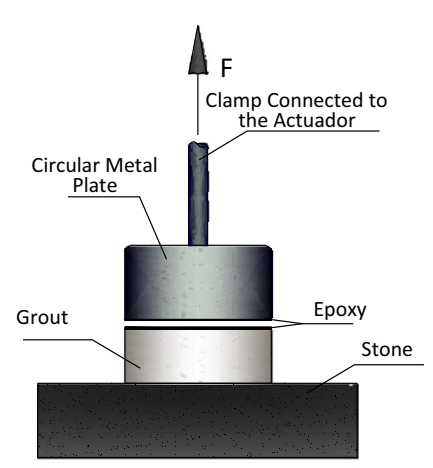

(b)

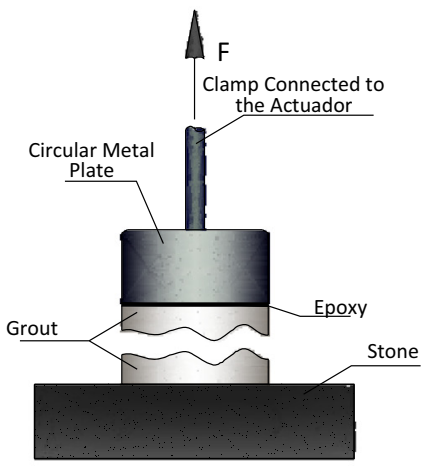

(c)

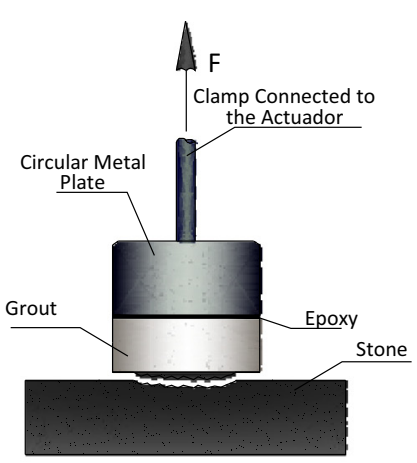

(d)

Fig. 6. Fracture type scheme: (a) interface; (b) glue; (c) grout and (d) stone. 
Table 5

Summary of tensile tests performed with YG. Coefficients of variation (\%) are indicated in brackets

\begin{tabular}{|c|c|c|c|c|}
\hline $\begin{array}{l}\text { Stone moisture } \\
\text { content }\end{array}$ & Grout & $\begin{array}{l}\text { Tensile bond strength } \\
\text { (MPa) } \\
28 / 90 \text { days }\end{array}$ & $\begin{array}{l}\text { Type of fracture } \\
28 / 90 \text { days }\end{array}$ & Notes \\
\hline $\begin{array}{l}\text { Wet } \\
\qquad(\mathrm{H}=1.3 \%)\end{array}$ & $\begin{array}{l}A \\
B \\
C \\
D\end{array}$ & $\begin{array}{l}0.97(14.7) / 1.26(16.6) \\
0.33(30.1) / 0.40(8.1) \\
0.02(-) / 0.58(17.2) \\
0.32(16.2) / 0.50(20.7)\end{array}$ & $\begin{array}{l}\text { Interface/Stone } \\
\text { Stone/Stone } \\
\text { Interface/Interface } \\
\text { Interface/Stone } \\
\text { + Interface }\end{array}$ & $\begin{array}{l}- \\
- \\
\text { Only } 1 \text { specimen at } 28 \text { days } \\
\text { Rupture mixed at } 90 \text { days ( } 50 \% \text { grout }+50 \% \text { interface) }\end{array}$ \\
\hline $\begin{array}{l}\text { Saturated } \\
\qquad(\mathrm{H}=2.8 \%)\end{array}$ & $\begin{array}{l}A \\
B \\
C \\
D\end{array}$ & $\begin{array}{l}0.23(26.5) / 0.67(11.2) \\
-/ 0.32(17.6) \\
-/ 0.44(18.9) \\
0.085(-) / 0.18(20.6)\end{array}$ & $\begin{array}{l}\text { Interface/Interface } \\
\text {-/Interface } \\
\text {-/Interface } \\
\text { Grout/Interface + Stone }\end{array}$ & $\begin{array}{l}\text { Only } 2 \text { specimens at } 90 \text { days } \\
- \\
\text { Rupture of } 1 \text { specimen at } 28 \text { days. Rupture mixed at } 90 \text { days ( } 50 \% \text { grout }+50 \% \\
\text { interface) }\end{array}$ \\
\hline $\begin{array}{l}\text { Dry } \\
\qquad(\mathrm{H}=0.8 \%)\end{array}$ & $\begin{array}{l}A \\
B \\
C \\
D\end{array}$ & $\begin{array}{l}0.53(26.9) / 0.67(11.2) \\
0.32(14.3) / 0.29(24.2) \\
0.21(-) / 0.66(13.5) \\
0.16(19.0) / 0.76(29.2)\end{array}$ & $\begin{array}{l}\text { Grout/Stone } \\
\text { Stone/Stone } \\
\text { Interface/Interface } \\
\text { Interface/Interface } \\
\text { + Stone }\end{array}$ & $\begin{array}{l}- \\
- \\
\text { Only } 1 \text { specimen at } 28 \text { days } \\
\text { Rupture mixed at } 90 \text { days } \\
\text { (50\% grout }+50 \% \text { interface) }\end{array}$ \\
\hline
\end{tabular}

Table 6

Summary of tensile tests performed with LM. Coefficients of variation (\%) are indicated in brackets

\begin{tabular}{|c|c|c|c|c|}
\hline Stone moisture content & Grout & $\begin{array}{l}\text { Tensile bond strength }(\mathrm{MPa}) \\
\text { 28/90 days }\end{array}$ & $\begin{array}{l}\text { Type of fracture } \\
28 / 90 \text { days }\end{array}$ & Notes \\
\hline $\begin{array}{l}\text { Wet } \\
\qquad(\mathrm{H}=2.5 \%)\end{array}$ & $\begin{array}{l}A \\
B \\
C \\
D\end{array}$ & $\begin{array}{l}0.42(14.4) / 0.78(10.6) \\
-/- \\
-/- \\
-/ 0.14(-)\end{array}$ & $\begin{array}{l}\text { Interface/Interface } \\
-1- \\
-/- \\
-/ \text { Interface }\end{array}$ & $\begin{array}{l}- \\
\text { Failed during demoulding } \\
\text { Failed during demoulding } \\
\text { Only } 1 \text { specimen at } 90 \text { days }\end{array}$ \\
\hline $\begin{array}{l}\text { Saturated } \\
\qquad(\mathrm{H}=3.0 \%)\end{array}$ & $\begin{array}{l}A \\
B \\
C \\
D\end{array}$ & $\begin{array}{l}0.50(48.5) / 0.54(22.1) \\
-/- \\
0.34(10.5) /- \\
0.21(50.7) /-\end{array}$ & $\begin{array}{l}\text { Interface/- } \\
-/- \\
\text { Interface/- } \\
\text { Grout/- }\end{array}$ & $\begin{array}{l}- \\
\text { Failed during demoulding } \\
-\end{array}$ \\
\hline $\begin{array}{l}\text { Dry } \\
\qquad(\mathrm{H}=0.5 \%)\end{array}$ & $\begin{array}{l}A \\
B \\
C \\
D\end{array}$ & $\begin{array}{l}0.45(17.5) / 0.46(14.3) \\
-/- \\
-/- \\
-/ 0.14(23.7)\end{array}$ & $\begin{array}{l}\text { Interface/Interface } \\
-1- \\
-1- \\
-/ \text { Grout }\end{array}$ & $\begin{array}{l}\text { Failed during demoulding } \\
\text { Failed during demoulding } \\
\text { _ }\end{array}$ \\
\hline
\end{tabular}

Table 7

Summary of tensile tests performed with SC. Coefficients of variation (\%) are indicated in brackets.

\begin{tabular}{|c|c|c|c|c|}
\hline Stone moisture content & Grout & Tensile bond strength (MPa) 28/90 days & Type of fracture $28 / 90$ days & Notes \\
\hline \multirow[t]{4}{*}{ Wet $(\mathrm{H}=2.0 \%)$} & $A$ & $0.48(32.7) / 0.71(10.2)$ & Interface/Interface & - \\
\hline & $B$ & $0.40(40.4) / 0.24(38.1)$ & Interface/Interface & - \\
\hline & $C$ & $-/ 0.20(-)$ & -/Interface & Only 1 specimen at 90 days \\
\hline & $D$ & $0.28(13.7) / 0.22(10.8)$ & Interface/Interface & Result of only 2 specimens at 90 days \\
\hline \multirow[t]{4}{*}{ Dry $(H=0.4 \%)$} & $A$ & $0.64(18.8) / 0.62(12.1)$ & Interface/Interface & The grout had granule stone \\
\hline & $B$ & $0.33(19.4) / 0.38(25.8)$ & Interface/Interface & Result of only 2 specimens at 90 days \\
\hline & $C$ & $0.01(-) /-$ & Interface/- & Only 1 specimen at 28 days \\
\hline & $D$ & $0.11(33.5) / 0.17(12.5)$ & Interface/Grout & 1 specimen failed in the interface at 90 days \\
\hline
\end{tabular}

the best results are obtained with granite in the "wet" condition. In this case, a bond stress of $1.26 \mathrm{MPa}$ was obtained at 90 days of age. Products $C$ and $D$ presented values near $0.7 \mathrm{MPa}$ in the "dry" state at 90 days of age, close to the values obtained at 28 days in the granite. Poor results were obtained in granite in the "wet" and "saturated" states. In limestone, the results are significantly worse than with granite. In this case, it was impossible to perform the test in the majority of the samples, as detachment of the grout occurred prior to the specimen being tested in the laboratory. For schist the results obtained are below those for granite, although grout $A$ had satisfactory results (see Figs. 8-10.

In conclusion, product A seems to have better and more uniform behaviour than the other grouts in all stones, even with different moisture contents. The lowest value obtained for this product, with saturated granite, was $0.23 \mathrm{MPa}$.

The absence of water in the support may also influence the hydration of the binder material, since some of the mixing water is absorbed by the substrate, thus reducing the hardening and strength capacity. On the other hand, it is understandable that rougher supports provide an increase in the bond capacity of the material. Analyzing the results obtained in the present experimental work, it seems that there is no single factor that explains the data obtained for the bond strength of commercial grouts. In general, good results were obtained for the stone with lower porosity and water absorption (see Table 8). However, the surface of granite apparently has greater roughness than the other two stones. 


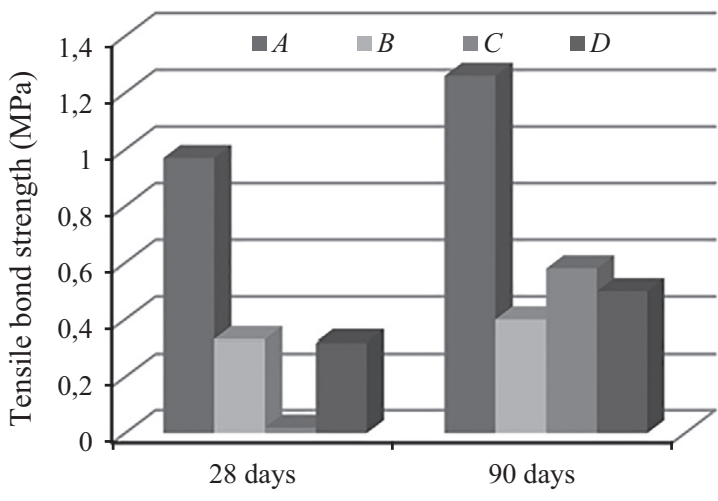

(a)

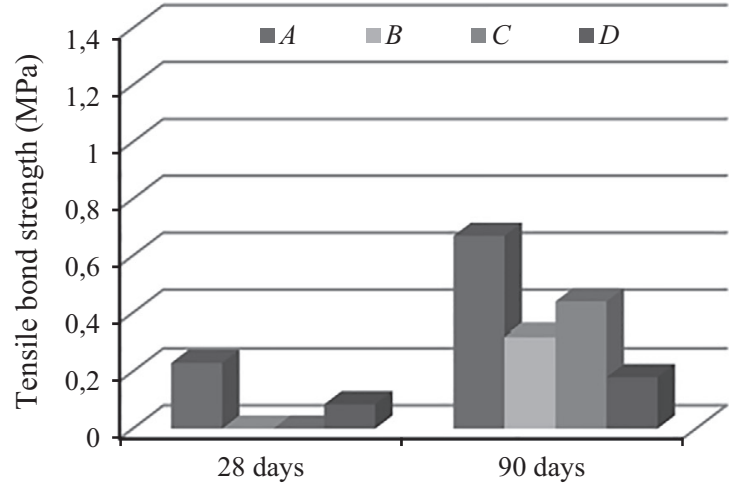

(b)

Fig. 7. Results in YG: (a) "wet”; (b) "saturated".

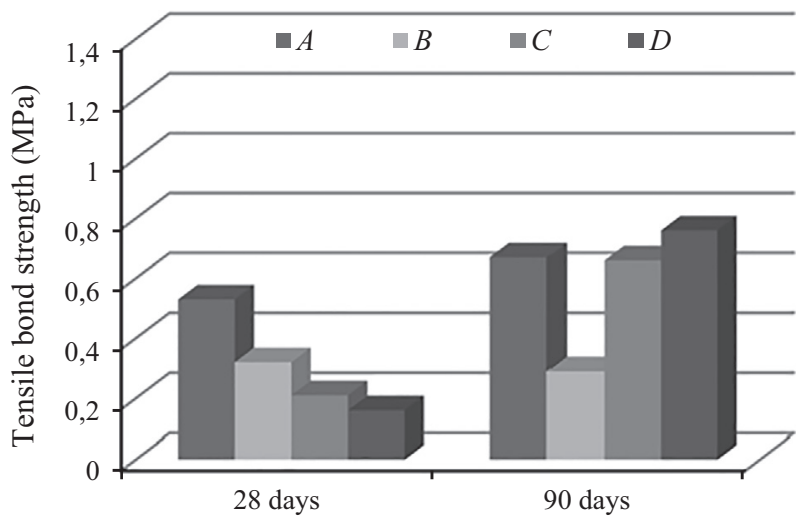

Fig. 8. Results in YG "dry"

Reasonable results were also obtained for "dry" granite, which allowed the conclusion that even with low porosity and no excess of water, the bond strength appears to be more effective with more roughness, but this property is also linked to the type of grout used and to the petrographic characteristics of stones.

During testing, stone fracture was observed in granite, but only for grout $A$, which seems to provide a better mechanical connection between the support and the grout. The fracture by cohesion of stone was more pronounced in the "wet" than in the "dry" condition and increased with the age of the specimen. In schist stone in

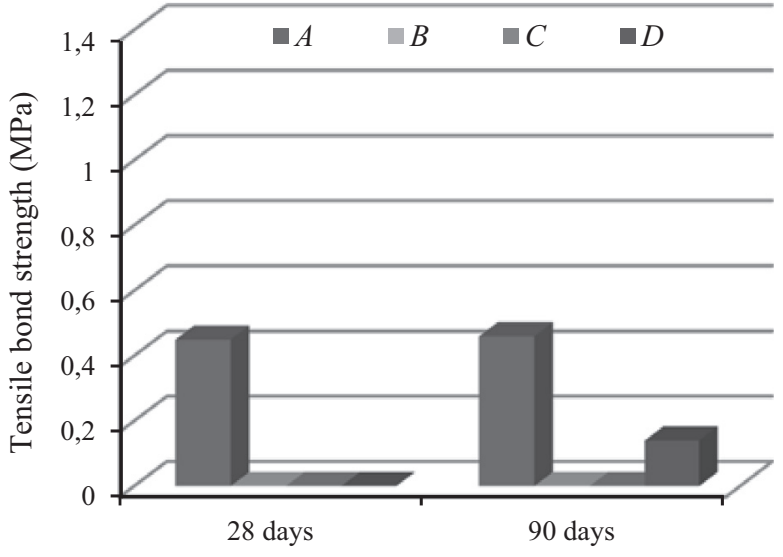

Fig. 10. Results in LM “dry".

the "dry" state, grout A showed fracture mainly in the "interface", but with a good bond and a slight detachment of the schist. This type of failure was not observed in the remaining grouts. Grouts $B$ and $C$ always exhibited an "interface" failure. The failure mode of grout $D$ was often a "grout" failure. Conversely, "glue" failure never occurred, which indicates that a proper epoxy was adopted in the tests. Figs. 12 and 13 show examples of each type of fracture observed during the tests.

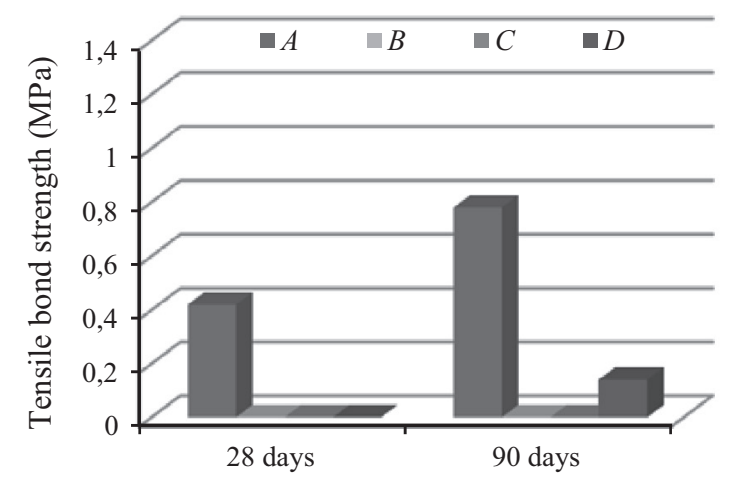

(a)

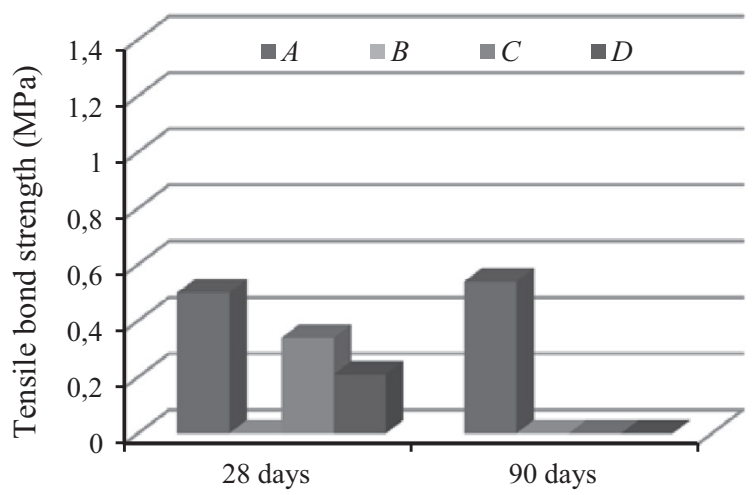

(b)

Fig. 9. Results in LM: (a) "wet"; (b) "saturated". 


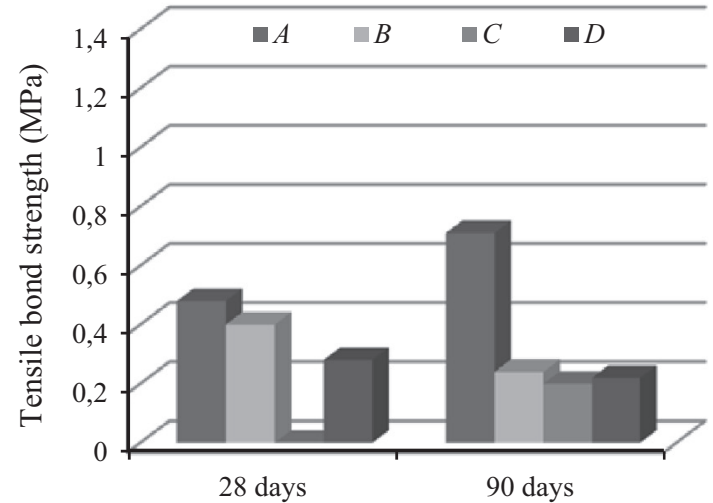

(a)

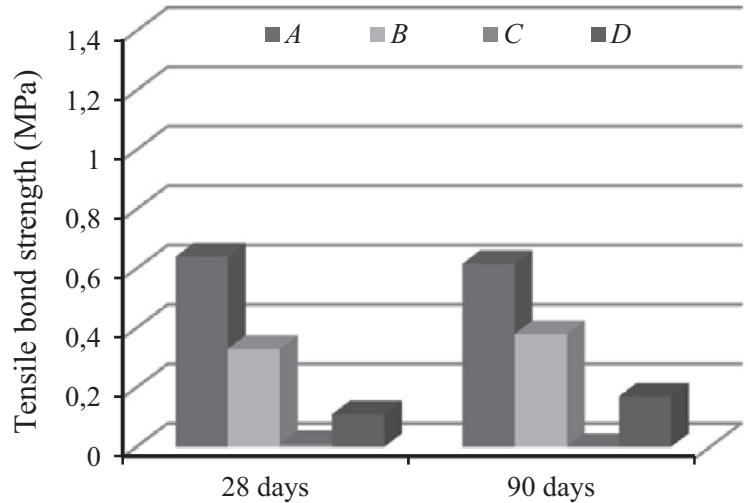

(b)

Fig. 11. Results in SC: (a) "wet”; (b) "dry".

Table 8

Physical characteristics of the stones used.

\begin{tabular}{|c|c|c|c|}
\hline & Yellow granite (YG) & Limestone (LM) & Schist (SC) \\
\hline Water absorption ${ }^{*}(\%)$ & 0,7 & 3,3 & 4,2 \\
\hline Porosity $^{*}(\%)$ & 1,9 & 8,1 & 10,2 \\
\hline Roughness $^{* *}$ & Greater roughness - thick grains & Minor roughness - fine grains & Variable roughness (smooth, rough and with cavities) \\
\hline
\end{tabular}

* Standard EN 1097-6 [41]

** Visual observation.
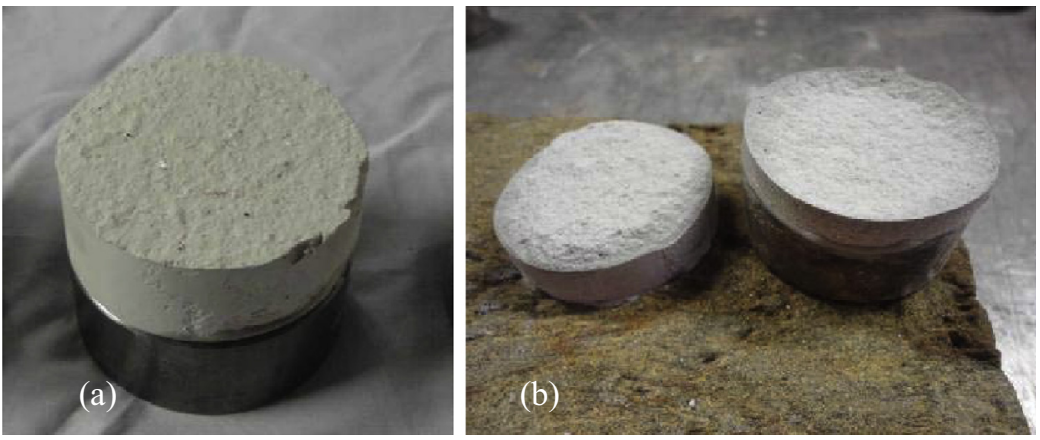

Fig. 12. Types of fracture observed: (a) "interface" with product $D$; b) "grout" with product $D$.
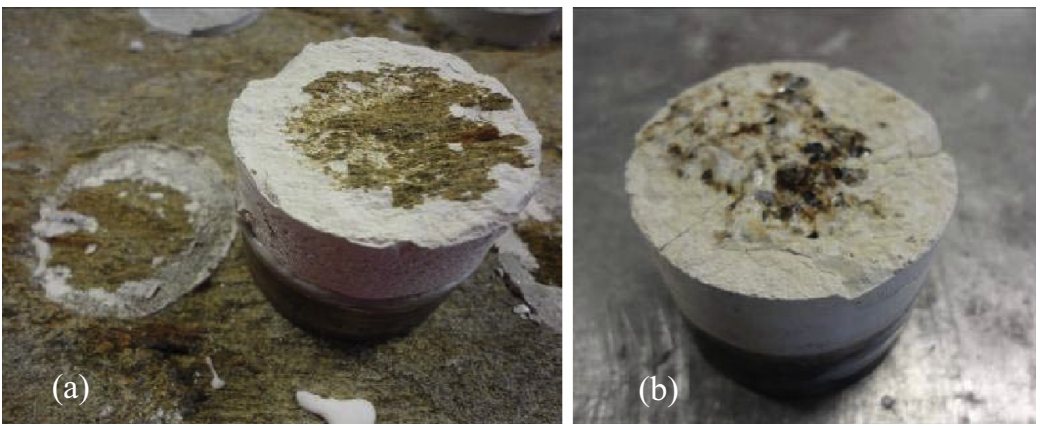

Fig. 13. Types of fracture observed: (a) interface + stone with product $A$ and "dry" schist; (b) "stone" with product A and "wet" granite.

\section{Conclusions}

Despite bond strength being one of the most important properties of the grout injection technique, this information is not present in the technical data sheets of commercial products. This is understandable as the strength depends significantly on the substrate and its condition. Standards that define the test setup and adopt normalized substrates seem to be necessary. The results of the cur- 
rent testing program indicate that there are significant differences among four commercial grout products studied using three types of stony supports (granite, limestone and schist). Significant differences in the results are also obtained for the same grout when varying the type of stone and the moisture content of the substrate. It is noted that, despite the fact that two grouts showed similar characteristics in terms of mechanical strength, the bond strength capacity verified is considerably different. The best commercial grout found revealed generally good results with an average tensile bond strength of $0.8 \mathrm{MPa}$ at 28 days of age for the three types of stone, but the other grout, with very similar mechanical characteristics in compression tests, revealed weak tensile bond strength values. This result confirms that a higher compression strength does not necessarily mean also higher values of bond strength capacity.

The failure mode of the best commercial grout found in granite occurred in the "interface" between stone and grout, and within the "stone" substrate itself, with significant loss of mineral fragments from the substrate. This did not occur with any other stone or grout. The results indicate that the bonding strength seems to be closely related to the roughness of the substrate, to the petrographic characteristics of the stone, to the moisture content of the substrate, and to the grout used.

\section{References}

[1] E. Vintzileou, Grouting of three-leaf stone masonry: types of grouts, mechanical properties of masonry before and after grouting, structural analysis of historical constructions, in: P.B. Lourenço, P. Roca, C. Modena, S. Agrawal (Eds.), Structural Analysis of Historical Constructions, 2006.

[2] S. Perret, G. Ballivy, D. Palardy, R. Laporte, Formulation of high-performance cement grouts for the rehabilitation of heritage masonry structures, in: Third International Conference on Grouting and Grout Treatment, New Orleans, Louisiana, 2003.

[3] F. Henriques, A conservação do património histórico edificado, (Memória 775), LNEC, 1991.

[4] E.-E.Toumbakari, D. Van Gemert, T.P. Tassios, E. Vintzileou, Effect of the mechanical properties of injection grouts on the structural behavior of threeleaf masonry walls, in: Proceedings of the 9th North American Masonry Conference, Clemson S.C, 2003.

[5] E.-E. Toumbakari, E. Vintzileou, T.P. Tassios, D. Van Gemert, Shear behaviour of masonry units \& lime-pozzolan-cement grout interfaces, in: Proceedings of the 9th North American Masonry Conference, Clemson S.C, 2003.

[6] D. Van Gemert, E.E. Toumbakari, S. Ignoul, K. Brosens, Consolidation and strengthening of historical masonry by means of mineral grouts: modeling structural behavior of grouted three-leaf masonry, Restor. Build. Monuments 21 (1) (2015) 47-54.

[7] C. Adami, E. Vintzileou, Interventions to historic masonries: investigation of the bond mechanism between stones or bricks and grouts, Mater. Struct. 41 (2008) 255-267.

[8] L. Binda, A. Fontana, G. Mirabella, Modelling of the mechanical behaviour of multi-leaf stone walls, in: Int. Symp. on Computer Methods in Structural Masonry, Swansea, 1991

[9] L. Binda, C. Modena, G. Baronio, Strengthening of masonries by injection technique, in: Proc. 6th NAMC (North American Masonry Conference), Philadelphia, 1993.

[10] E. Toumbakari, D. Van Gemert, T. Tassios, E. Vintzileou, Experimental investigation and analytical modelling of the effect of injection grouts on the structural behaviour of three-leaf masonry walls, in: 4th International Seminar on Structural Analysis of Historical Constructions, Padova, Italy, 2004, pp. 707717.

[11] E. Vintzileou, T.P. Tassios, Three-leaf stone masonry strengthened by injecting cement grouts, J. Struct. Eng. 121 (5) (1995) 848-856.

[12] M. Valluzi, F. Da Porto, C. Modena, Behavior and modeling of strengthened three-leaf stone masonry walls, Mater. Struct. 37 (3) (2004) 184-192.
[13] B. Silva, A.E. Pigouni, M.R. Valluzi, C. Modena, Calibration of analytical formulations predicting compressive strength in consolidated three-leaf masonry wall, Constr. Build. Mater. 64 (2014) 28-38.

[14] S. Ignoul, F. Van Rickstal, D. Van Gemert, Application of mineral grouts. Case study and impact on structural behaviour: Church of St. Catharina at Duisburg (B), in: Lourenço, Roca (Eds.), Structural Analysis of Historical Constructions, Modena,London, 2005.

[15] C. Adami, E. Vintzileou, E. Toumbakari, Investigation of the bond mechanism between stones or bricks and grouts, in: Lourenco, Agrawal, Roca (Eds.) Structural Analysis of Historical Constructions, Modena, New Delhi, 2006.

[16] M. Reda Taha, N. Shrive, The use of pozzolans to improve bond and bond strength, in: 9th Canadian Masonry Symposium, Canada, 2001.

[17] V. Dubovoy, J. Ribar, Masonry cement mortars - a laboratory investigation, Portland Cement Association (PCA) Research and Development Bulletin RD095T, Skokie, USA, 1990.

[18] C. Groot, Effects of water on mortar-brick bond, publisher not identified, 1993.

[19] J. Grandet, J. Farran, J. Maso, Variations des concentrations de portlandite et d'etringite dans les pâts de ciment Portland au contact des terres cuites poreuses, Comptes Rendus, Acad. Sc. Paris, 1970.

[20] R. Atkinson, M. Schuller, Development of injectible grouts for the repair of unreinforced masonry, in: Proceedings of the Workshop on Effectiveness of Retrofitting of Stone and Brick Masonry Walls in Seismic Areas, Dept. of Struct. Engrg., Politecnico di Milano, Milan, Italy, 1992.

[21] W. McGinley, IRA and the flexural bond strength of clay brick masonry masonry: components to assemblages, in: J.H. Mathys (Ed.), ASTM 1063, 1990 pp. 217-234.

[22] M. Reda Taha, A. El-Dieb, N. Shrive, Sorptivity: a reliable measurement for surface absorption of masonry brick units, Mater. Struct. 34 (2001) 438-445.

[23] M.R. Valluzzi, F. Da Porto, C. Modena, Behaviour of multi-leaf stone masonry walls strengthened by different intervention techniques, Historical Constr. (2001) 1023-1032.

[24] D. Laefer, G. Baronio, A. Anzani, L. Binda, Measurement of grout injection efficacy for stone masonry walls, Seventh North American Masonry Conference, University of Notre Dame, Indiana, USA, 1996.

[25] A.E. Miltiadou, Etude des coulis hydrauliques pour la réparation et le renforcement des structures et des monuments historiques en maçonnerie, (No. OA8), 1991

[26] A. Figueiredo, Injection Grouts for Ancient Masonry - Adherence Study, Seventh North American Masonry Conference, Civil Engineering Department, Instituto Superior Técnico, Universidade Técnica de Lisboa, 2013.

[27] E. Vintzileou, T.P. Tassios, Three-leaf stone masonry strengthened by injecting cement grouts, J. Struct. Eng. 121 (5) (1995) 848-856.

[28] E. Toumbakari, E. Vintzileou, F. Pisano, D. Van Gemert Experimental investigation of three-leaf masonry walls, in: Proc. 1st National Congress on Mild Interventions and Protection of Historic Structures, Thessaloniki, Greece, 2000.

[29] A. Miltiadou-Fezans, T.P. Tassios, Fluidity of hydraulic grouts for masonry strengthening, Mater. Struct. 45 (12) (2012) 1817-1828.

[30] A. Miltiadou-Fezans, T.P. Tassios, Penetrability of hydraulic grouts, Mater Struct. 46 (10) (2013) 1653-1671.

[31] E. Luso, P.B. Lourenço, Experimental characterization of commercial lime based grouts for stone masonry consolidation, Constr. Build. Mater. 102 (2016) $216-225$.

[32] EN 445, Grout for prestressing tendons, Test methods, 2008.

[33] ASTM C940-10a, Standard Test Method for Expansion and Bleeding of Freshly Mixed Grouts for Preplaced-Aggregate Concrete in the Laboratory, 2010.

[34] EN 196-1, Methods of testing cement; Part 1 Determination of strength, 2006

[35] L. Binda, G. Baronio, C. Tiraboschi, C. Tedeschi, Experimental research for the choice of adequate materials for the reconstruction of the Cathedral of Noto, Constr. Build. Mater. 17 (2003) 629-639.

[36] E 397, Betões. Determinação do módulo de elasticidade em compressão, LNEC, 1993.

[37] ASTM C469/C469M-10, Standard test method for static modulus of elasticity and Poisson's ratio of concrete in compression, 2010.

[38] EN 12390-6, Testing hardened concrete. Part 6: Tensile splitting strength of test specimens, 2009.

[39] S. Perret, H. Khayat, E. Gagnon, J. Rhazi, Repair of 130-year old masonry bridge using high-performance cement grout, J. Bridge Eng. 7 (1) (2002) 31-38.

[40] A. Sá, V. Freitas, Cementitious adhesives performance during service life, International Conference On Durability of Building Materials and Components, FEUP, 2005.

[41] EN 1097-6, Tests for mechanical and physical properties of aggregates; Part 6 : Determination of particle density and water absorption, 2013. 